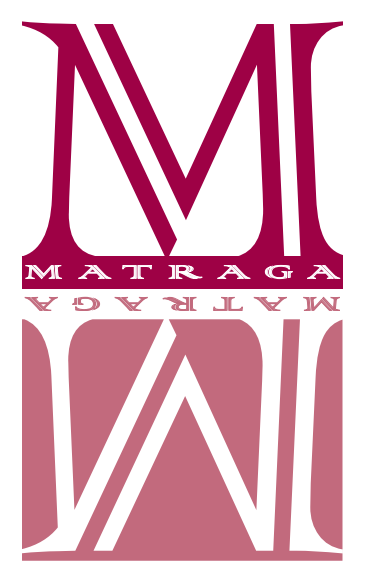

\title{
Os falares sulista e fluminense de Antenor Nascentes e sua realidade nos dados do projeto AliB
}

\author{
Valter Pereira Romano \\ Universidade Federal de Santa Catarina \\ https://orcid.org/0000-0002-8882-3188 \\ Leandro Almeida dos Santos \\ Universidade Federal da Bahia \\ https://orcid.org/0000-0001-9676-3018
}

\section{RESUMO}

O artigo apresenta uma discussão acerca da divisão dialetal do Português Brasileiro proposta por Antenor Nascentes (1953). O texto objetiva discutir a divisão de Nascentes no que respeita aos subfalares sulista e fluminense, pautando-se em dados do léxico coletados para a elaboração do Atlas Linguístico do Brasil (CARDOSO et al., 2014). Para tanto, consideram-se análises realizadas por Romano (2015) e por Santos (2016) que caracterizam as áreas sob a perspectiva da variação lexical e dão indícios da necessidade de uma reformulação.

PALAVRAS-CHAVE: Projeto ALiB; Áreas lexicais; Antenor Nascentes.

\section{Antenor Nascentes' Southern and Fluminense Speeches and its Reality in Project AliB's Data}

\section{ABSTRACT}

The article presents a discussion about dialectal division of Brazilian Portuguese as proposed by Antenor Nascentes (1953). The text aims to discuss the division of Nascentes in relation to the southern and fluminense (from Rio de Janeiro state) subspeech, based on lexical data collected for the elaboration of the Linguistic Atlas of Brazil (CARDOSO et al., 2014). For this purpose, analyses carried out by Romano (2015) and Santos (2016) are considered, which characterize the areas from the perspective of lexical variation and give evidence of the need for a reformulation.

KEYWORDS: ALiB Project; Lexical areas; Antenor Nascentes. 


\section{Introdução}

A obra O linguajar carioca em 1922, de Antenor Nascentes, em sua primeira edição, trouxe uma das primeiras tentativas de apresentação de um mapa dialetológico para o Brasil. Essa proposta de divisão dos falares brasileiros foi reformulada em 1933, publicada na segunda edição do livro, em 1953, tem servido de baliza para a descrição diatópica do português brasileiro (PB), e, até os dias de hoje, é amplamente referenciada por estudiosos de variação linguística, em especial, geolinguistas e dialetólogos.

Os pesquisadores do Projeto Atlas Linguístico do Brasil ${ }^{1}$ (Projeto ALiB) têm seguido de perto a divisão de Nascentes (1953) com trabalhos que ora confirmam a proposta, ora suscitam a necessidade de uma reformulação, à medida que avança com estudos prévios de dados coletados no interior do país. São sobre os resultados encontrados em dois desses estudos, o de Romano (2015) e o de Santos (2016), que este texto trata, objetivando discutir a validade da proposta de Nascentes (1953) para duas áreas específicas, descriminadas pelo dialetólogo, a área do subfalar sulista e a área do subfalar fluminense, ambas pertencentes a um dos dois grandes grupos de falares: o falar do Sul.

Este artigo divide-se em seis seções, incluindo essa introdução e as conclusões. A próxima seção apresenta as propostas de divisão dialetal do PB. Na seção 3, apresenta-se o Projeto ALiB e algumas considerações acerca dos estudos de natureza lexical, elaborados a partir do banco de dados do referido Projeto. A seção 4 destina-se a apresentar os resultados encontrados na pesquisa de Romano (2015) acerca da área do subfalar sulista, e a seção 5, acerca da área do subfalar fluminense, investigada por Santos (2016). Seguem-se, por fim, a conclusões e as referências mencionadas.

\section{As propostas de divisões dialetais do Brasil}

Os trabalhos de natureza geolinguística têm por finalidade apresentar um conjunto de dados que comprove ou não a existência de áreas dialetais em determinado espaço geográfico, uma vez que os dados linguísticos coletados empiricamente são registrados em "mapas especiais" (COSERIU, 1987).

Embora Amaral (1981, p. 44 [1920]) já apontasse a necessidade de trabalhos empíricos com a finalidade de retratar "com segurança quais os caracteres gerais do dialeto brasileiro, ou dos dialetos brasileiros”, as tentativas de divisão e sistematização de tais 'dialetos' vieram a se consolidar na obra O linguajar carioca em 1922, de Antenor Nascentes (1922/1953). Nessa obra, o autor apresenta as primeiras propostas como, por exemplo, a de Júlio Ribeiro (1881), considerada por Nascentes (1953) como "toda ela imperfeita", pois Ribeiro pautou-se, exclusivamente, no critério geográfico. Na ocasião, Ribeiro dividiu o Brasil em quatro áreas: 1) Norte; 2) Leste; 3) Centro; 4) Sul, conforme se observa na Figura 1.

\footnotetext{
1 Mais informações sobre o Projeto ALiB podem ser encontradas no site: Disponível em: < https://alib.ufba.br/> Acesso em: 07 jul. 2020.
} 
FIGURA 1. Divisão dialetal de Júlio Ribeiro (1881)

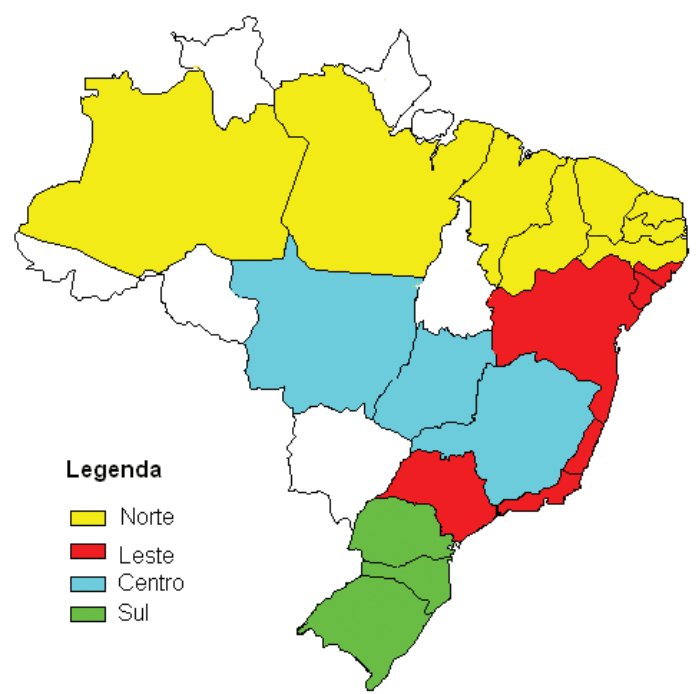

Fonte: Elaborado a partir da descrição de Nascentes (1953, p. 21).

Nascentes (1953) destaca os seguintes defeitos nessa divisão:

Junta o Norte com Nordeste, que é muito diferente dele.

Separa Alagoas dos demais Estados do Nordeste.

Coloca o Espírito Santo (sem discriminar norte e sul) e Rio de Janeiro junto da Baía, tão diferente esta.

Coloca São Paulo, tão caracteristicamente sulino, junto com Alagoas (!) e junto com Sergipe e Baía e junto com Espírito Santo e Rio de Janeiro.

Coloca Minas (sem descriminar sic) junto com Goiás e Mato Grosso.

No sul só ha que objetar a falta de S. Paulo (NASCENTES, 1953, p. 21).

Dando continuidade, Nascentes (1953) descreve a proposta de Maximino Maciel (1950), conforme se observa na Figura 2.

FIGURA 2. Divisão dialetal de Maximino Maciel (1950)

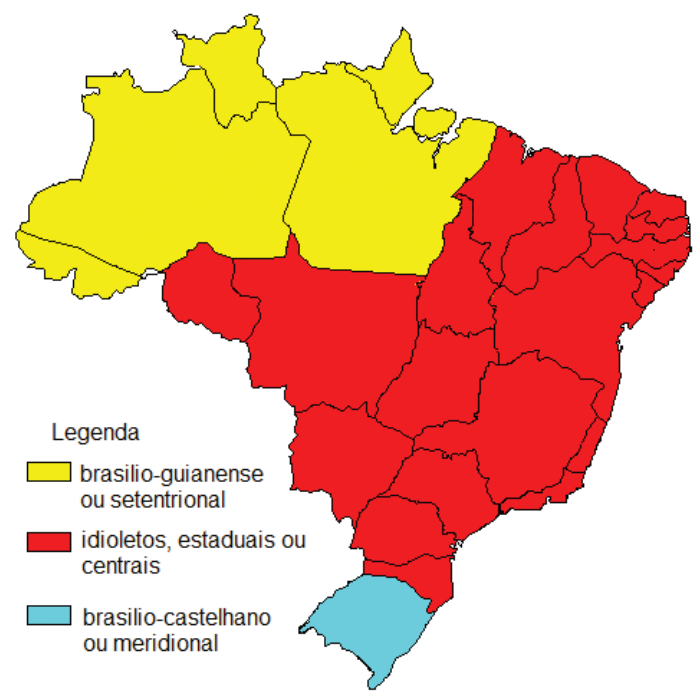

Fonte: Elaborado a partir da descrição de Nascentes (1953, p. 21) e também Barbadinho Neto citado em Ribeiro (2012). 
Segundo Nascentes (1953), essa divisão, além de se pautar, exclusivamente, no critério geográfico, apresenta outros defeitos como:

A língua chamada Guiana Brasileira se estende à região da margem direita do Amazonas; que serão idioletos? A influência do castelhano platino na língua da fronteira com o Uruguai e com a Argentina não vai ao ponto de dominar um subfalar (NASCENTES, 1953, p. 21).

Conclui que, sem uma base histórica, não se pode fazer nada sobre o assunto. Nesse sentido, a proposta de divisão do historiador João Ribeiro, constante da obra História do Brasil, vem contribuir, pois agrupa o "imenso organismo nacional" (NASCENTES, 1953, p. 23) em cinco grupos locais:

1) o Extremo Norte (a Amazônia, o Maranhão, Piauí, e Ceará); 2) o Norte (Alagoas, Pernambuco, Paraíba e Rio Grande do Norte; 3) o Centro (Sergipe, Baía, Ilhéus e Porto Seguro); 4) o Interior (São Paulo, Minas Gerais, Goiás e Mato Grosso); 5) o Sul (Espírito Santo, Rio de Janeiro, Santa Catarina e Rio Grande do Sul) (NASCENTES, 1953, p. 23).

Nascentes (1953) pondera apresentando outra proposta de divisão dialetal, a de Rodolfo Garcia, publicada no Dicionário de brasileirismos (1915). Garcia combinou o critério geográfico com o histórico, levando "em conta a continuidade territorial, a facilidade de comunicações terrestres, marítimas, fluviais (naquele tempo, 1915, não havia ainda as aéreas), a homogeneidade ou heterogeneidade de culturas" (NASCENTES, 1953, p. 22). Assim, considerando a distribuição geográfica dos localismos compendiados nos diferentes glossários, Garcia delimitou cinco zonas, conforme se observa na Figura $3^{2}$ :

FIGURA 3. Divisão Dialetal de Rodolfo Garcia (1915)

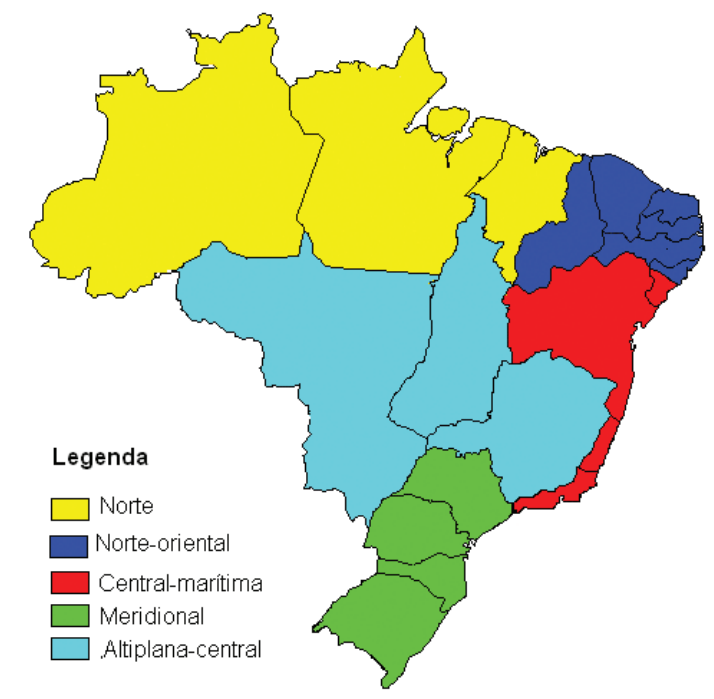

Fonte: Elaborado a partir da descrição de Nascentes (1953, p. 22).

2 Em 1915, os atuais Estados do Amapá, Roraima, Acre e Rondônia eram Territórios Federais. 0 Estado do Mato Grosso do Sul foi desmembrado do Mato Grosso em 1977 e o Estado do Tocantins foi criado em 1988. Fonte: Disponível em: <http://www. sogeografia.com.br/Conteudos/Estados/>. Acesso: 01 jul. 2020. 
Nascentes (1953) considera positivos os pontos referentes à combinação de critérios históricos e geográficos, porém, não deixa de tecer algumas críticas a essa divisão.

Ha os seguinte (sic) defeitos nesta divisão: colocar o Maranhão na zona Norte, quando ele é uma espécie de intermediário entre ela e o Nordeste; colocar o Rio de Janeiro e o sul do Espírito Santo na zona central-maritima; colocar Minas Gerais (sem discriminar) e Goiás junto com Mato Grosso (NASCENTES, 1953, p. 22).

Considerando a divisão de Rodolfo Garcia, Antenor Nascentes, em O linguajar carioca em 1922, apresenta a sua divisão dialetal do Brasil, agrupando os falares brasileiros em quatro áreas: 1) nortista; 2) fluminense; 3) sertaneja; 4) sulista, conforme se observa na Figura 4.

FIGURA 4. Divisão Dialetal de Antenor Nascentes (1922)

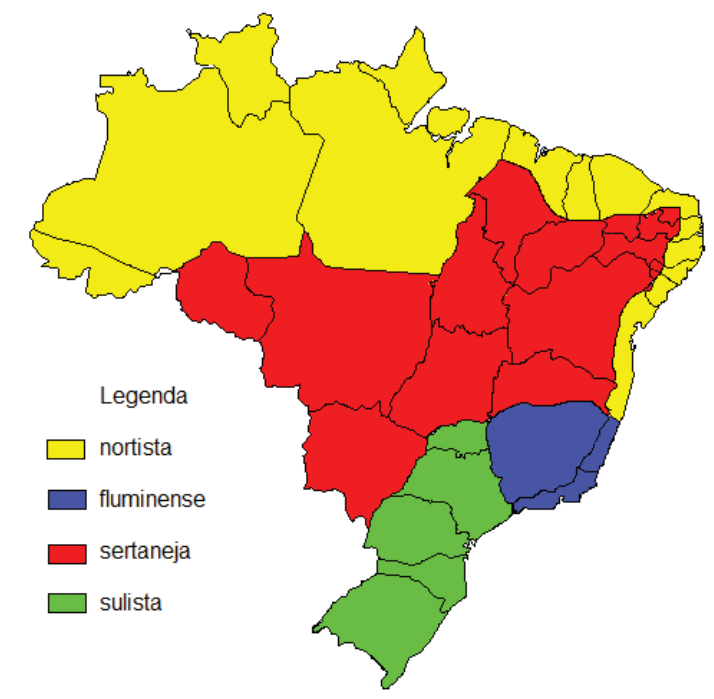

Fonte: Elaborado a partir da descrição de Nascentes (1953, p. 23).

Essa proposta de divisão dialetal recebeu críticas de Lindolfo Gomes e o próprio Nascentes reconheceu a falha, pois, na época, havia percorrido apenas uma pequena parte do território brasileiro: "Conhecia Minas, Espírito Santo, Estado do Rio, São Paulo, Paraná, Santa Catarina, Rio Grande do Sul, Recife e Baía" (NASCENTES, 1953, p. 23).

Atendendo às ponderações de Gomes, publicou, em 1933, o mapa dialetológico do Brasil com algumas alterações. Segundo Nascentes (1953), "Criei uma zona Norte para Amazonas e Pará, constituí uma zona Nordeste com o litoral, do Maranhão ao norte do Espírito Santo, passei o Sul de Minas para o subdialeto sulista" (NASCENTES, 1953, p. 23-24).

Porém, a reformulação do mapa, em 1933, também foi criticada. Na obra Influência africana no português do Brasil, Renato Mendonça (1935) reforça que o equívoco de tal divisão consistia em fazer entrar no subdialeto sulista regiões dialetologicamente diversas como São Paulo e Rio Grande do Sul. Para Mendonça, a linguagem da Amazônia distingue-se nitidamente de Pernambuco ou da Baía, todos enfeixados no subdialeto nortista (NASCENTES, 1953, p. 24). 
Nascentes, por sua vez, refuta as críticas de Mendonça, afirmando:

O Rio Grande do Sul, com que Rodolfo Garcia quase constituiu uma zona à parte, é muito típico, por vários motivos, mas não a ponto de destacar-se das linhas fundamentais do subfalar sulista.

Por conseguinte, está muito bem, junto com São Paulo.

$\mathrm{Na}$ ânsia de censurar, Mendonça esqueceu-se de que o erro de colocar a Amazonia junta com o litoral do Maranhão à Baía, cometido na divisão de 1922, já tinha sido sanado em 1933, na pág. 244 da quarta série do Idioma Nacional por ele citada na pág. 202 de A influência africana.

Hoje que já realizei o meu ardente desejo de percorrer todo o Brasil, do Oiapoc ao Xuí, de Recife a Cuiabá, fiz nova divisão que não considero nem posso considerar definitiva, mas sim um tanto próxima da verdade [...] Dividi o falar brasileiro em seis subfalares que reuni em dois grupos a que chamei do norte e do sul (NASCENTES, 1953, p. 24-25).

Dessa forma, na segunda edição de O linguajar carioca (1953), Nascentes apresenta um novo mapa dialetológico do Brasil. Com base em critérios prosódicos e fonéticos, a cadência e a abertura das vogais médias ([e] / [o]) em posição pretônica, o dialetólogo divide o PB em seis subfalares, compreendidos em dois grandes grupos, os falares do Norte e os falares do Sul, conforme se observa na Figura 5.

FIGURA 5. Divisão Dialetal de Antenor Nascentes (1953)

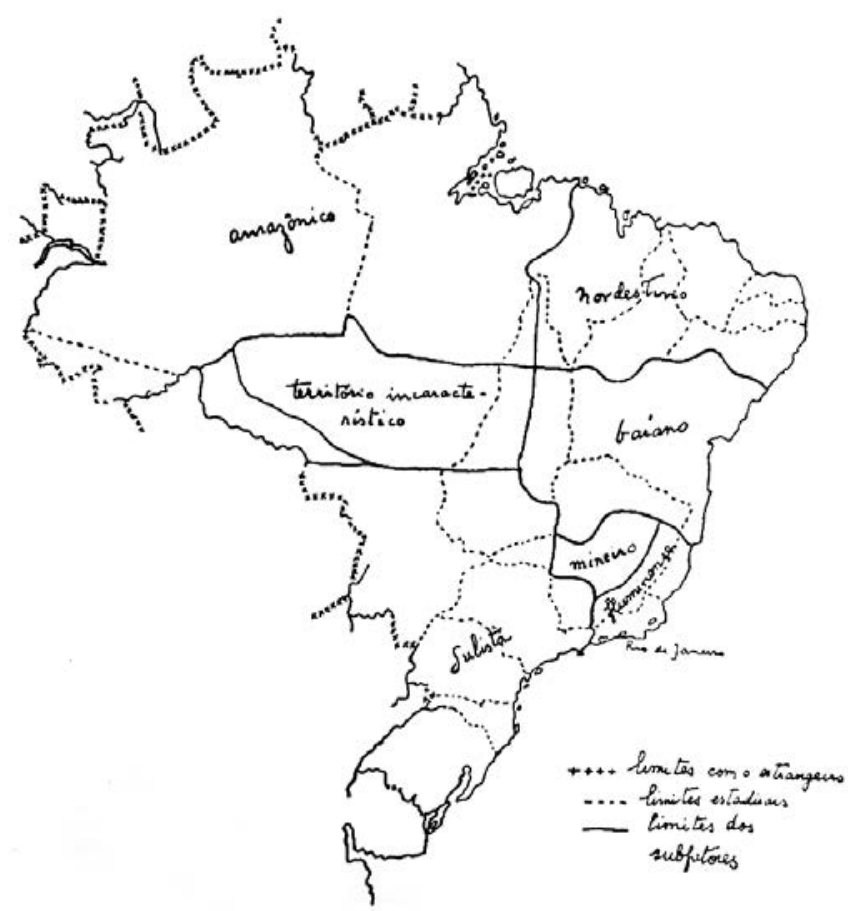

Fonte: Nascentes (1953, p. 18-19).

A divisão de Nascentes (1953) é muito referenciada entre os dialetólogos e tem servido de base, segundo Teles (2018, p. 40), "para quase todos os estudos de natureza geolinguística que buscam confirmar e atestar a pertinência dessa divisão nos dias atuais, identificando novas áreas dialetais e, consequentemente, novas divisões ou subdivisões". Apesar da imprecisão dos limites, pela carência de elementos de localização geográfica ou mesmo uma escala que permitisse 
afirmar com mais exatidão os limites de cada falar e subfalar, a divisão de Nascentes (1953) tem sido de perto acompanhada pelos pesquisadores do Projeto ALiB.

Aliás, Teles (2018) dedicou-se, exaustivamente, ao estudo desse mapa, sob a perspectiva da cartografia temática, utilizando-se ferramentas de georreferenciamento. Também, os pontos sugeridos por Nascentes para elaboração do atlas nacional, em 1958, foram analisados e reorganizados. Ao concluir o estudo, a referida autora apresenta marcos fundamentais para as pes-

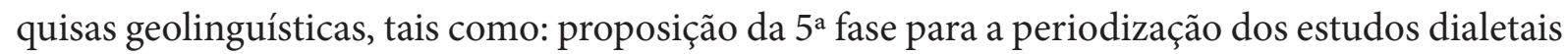
brasileiros; um mapa com todos os vértices definidores dos delineamentos feitos por Nascentes (1953); e um mapa atualizado com todas as localidades sugeridas por Nascentes (1958).

Mota (2006), ao fazer uma retrospectiva das divisões dialetais, ressalta que, até hoje, não foi proposta uma nova divisão, mesmo havendo um substancial avanço dos estudos dialetológicos e geolinguísticos. Isso se deve, sobretudo, à dificuldade de intercomparação entre os dados publicados nos atlas estaduais e regionais, seja pela adoção de metodologias distintas, seja pela distância temporal que se instituiu entre as publicações (APFB - 1963 ao ALERS - 2002). Para Mota (2006), atualmente, faz-se necessário um maior conhecimento das áreas dialetais brasileiras, "especialmente daquelas que ainda não dispõem de atlas regionais assim como de uma amostra atualizada, recolhida simultaneamente, com mesma metodologia e sob coordenação geral em todo o País" (MOTA, 2006, p. 351). Nesse sentido, os dados coletados para o Atlas Linguístico do Brasil (CARDOSO et. al., 2014) podem contribuir para uma nova proposta de divisão dialetal cientificamente justificável, conforme sinalizou o próprio Nascentes: "Nosso trabalho, repetimos, não é e nem podia ser definitivo. Aguardemos o Atlas Lingüístico do Brasil (até quando?), para um trabalho definitivo" (NASCENTES, 1955, p. 99).

\section{As divisões dialetais sob a perspectiva da variação lexical}

Como se sabe, as propostas de divisão dialetal de Nascentes (1953) foram pautadas em aspectos fonéticos e prosódicos do $\mathrm{PB}$ e, de certa forma, são confirmadas com trabalhos desta natureza, como os de Cardoso (1986; 1999), acerca da abertura das vogais médias em posição pretônica. Discutir as áreas dialetais a partir do léxico, apesar de os estudos apontarem diferenças interessantes, é uma tarefa desafiadora, dada a dinamicidade da língua e a difusão de variantes pelo espaço geográfico, por conta dos movimentos humanos de migração/imigração.

Uma das primeiras iniciativas, com dados do Projeto ALiB, é a de Aguilera (2009), que revisita dados lexicais para discutir a proposta de Nascentes (1953), quanto à validade e atualidade daquela divisão, apontando que à época do dialetólogo "faltavam - e ainda faltam - no entanto, estudos que pudessem/possam determinar as isoglossas" (AGUILERA, 2009, p. 4220).

Conforme bem assinala a autora, não é só no Brasil que os dialetólogos têm buscado definir áreas dialetais sob a perspectiva lexical. Cintra (1995) apresenta divisões dialetais em Portugal a partir de variantes lexicais registradas nos inquéritos do Atlas Linguístico da Península Ibérica (ALPI), documentando com uma série de mapas, como o das variantes lexicais para "cabrito" (ao norte e oeste) e "chibo" (no sul e leste) e os designativos para a "espiga de milho" em duas áreas delimitadas: "espiga" correspondendo ao centro nordeste de Portugal e "maçaroca" do noroeste ao sul do país. 
Aguilera (2009) assinala que as áreas correspondentes aos subfalares apontados por Nascentes (1953) devem ser revistas e estudadas de forma mais pormenorizada.

O falar do Sul, que Nascentes dividiu em subfalares, porém, além de demonstrar menor uniformidade ainda não traz, pelo menos nas variantes aqui analisadas, a divisão nos subfalares fluminense, mineiro e sulista. A denominação deste último eu substituiria por subfalar paulista que considero mais apropriada para designar a variante de grande parte dos territórios dos Estados de São Paulo, Paraná, Mato Grosso, Mato Grosso do Sul, e partes menores de Goiás e Santa Catarina. Nesta minha proposta, reservaria a denominação sulista para a variante do Rio Grande do Sul, que, pelo menos no nível lexical que aqui analisamos, se constitui diferentemente dos demais Estados. Justifico a denominação de subfalar paulista considerando a influência dos paulistas que adentraram o Brasil a partir do século XVII, intensificada nos séculos posteriores em direção ao sul de Minas Gerais, Goiás, Mato Grosso (inclusive o atual Mato Grosso do Sul), Paraná e parte de Santa Catarina (AGUILERA, 2009, p. 4232).

Não seria, então, agora que já se possui a documentação empírica do português falado no Brasil, a oportunidade de discutir a proposta de divisão dialetal de Nascentes (1953) e propor um novo mapa dialetológico para o Brasil?

Alguns trabalhos com o corpus do Projeto ALiB têm sido realizados. Limitando-se aos dados de natureza lexical, Ribeiro (2012) se encarregou de estudar o subfalar baiano, Portilho (2013) ateve-se à descrição do subfalar amazônico, Romano (2015) investigou a área do subfalar sulista, Santos (2016) analisou o subfalar fluminense, D’Anunciação (2016) em partes do subfalar mineiro, e, por fim, até então, Santos (2018) examinou o subfalar nordestino. Geralmente, "Essas pesquisas atestam que esses subfalares não se limitam à faixa territorial estabelecida por Nascentes, mas adentram outras áreas" (ROMANO, 2018, p. 119).

Este artigo trata do grupo dos subfalares do Sul, em consonância com as ideias de Aguilera (2009), que, ao conjunto dos subfalares fluminense, mineiro e sulista, podem ser incluídos outros subfalares, como, por exemplo, o subfalar paulista, principalmente, pelo foco de irradiação e a importância do movimento dos bandeirantes no território brasileiro. Não estaria esse grande subfalar sulista de Nascentes contemplando outros subfalares não discriminados pelo dialetólogo? E o subfalar fluminense, sob a perspectiva lexical, confirma-se ao ponto de diferenciação do subfalar sulista? Pretende-se responder a estas e outras perguntas após a análise dos dados de Romano (2015) e Santos (2016).

\section{0 subfalar sulista}

Romano (2015) defendeu como tese de doutorado na Universidade Estadual de Londrina a pesquisa intitulada Em busca de falares a partir de áreas lexicais no Centro-Sul do Brasil. Para tanto, dedicou-se a descrever, sob a perspectiva da geolinguística e da estatística inferencial, dados de natureza lexical de uma extensa área geográfica do território brasileiro que corresponde a oito unidades federativas: Rio Grande do Sul, Santa Catarina, Paraná, São Paulo, Mato Grosso do Sul, parte do estado do Mato Groso, centro-sul de Goiás, parte do sul de Minas Gerais e do Triângulo mineiro, que, basicamente, compreendem a área denominada por Nascentes (1953) como subfalar sulista. 
Após estudo criterioso da divisão de Nascentes (1953) e o georreferenciamento da rede de pontos do Projeto ALiB, a pesquisa buscou verificar a variação lexical para cinco questões do Questionário Semântico-Lexical (QSL) (COMITE NACIONAL DO PROJETO ALiB, 2001), a saber:

- 001 - CÓRREGO: “... o rio pequeno de dois metros de largura?”;

- 039 - TANGERINA: “... as frutas menores que a laranja, que se descascam com a mão, e, normalmente, deixam um cheiro nas mão?";

- 132 - MENINO: “... criança pequena de 5 a 10 anos, do sexo masculino?”;

- 156 - BOLINHA DE GUDE: “... as coisinhas redondas de vidro que os meninos gostam de brincar?";

- 177 - GELEIA: “... pasta feita de frutas para passar no pão, biscoito?”.

A rede de pontos da pesquisa refere-se a 118 municípios, sendo em cada um deles entrevistados quatro informantes, um homem e uma mulher de 18 a 30 anos e um homem e uma mulher de 50 a 65 anos, sumarizando a fala de 472 informantes de, no máximo, nível fundamental de escolaridade. A análise dos dados ateve-se à dimensão diatópica na distribuição dos itens, e buscou-se a explicação das principais formas documentadas à luz da sócio-história das localidades.

Para este texto, foi feito um recorte para apresentar algumas considerações de cunho comparativo de formas registradas, adaptando-se as cartas linguísticas constantes do trabalho de Romano (2015). A Figura 6 apresenta a distribuição areal das formas "chimia" (um dos designativos para questão 177) e "bergamota" (uma das variantes para questão 039):

FIGURA 6. Cartas linguísticas de "chimia" e "bergamota"
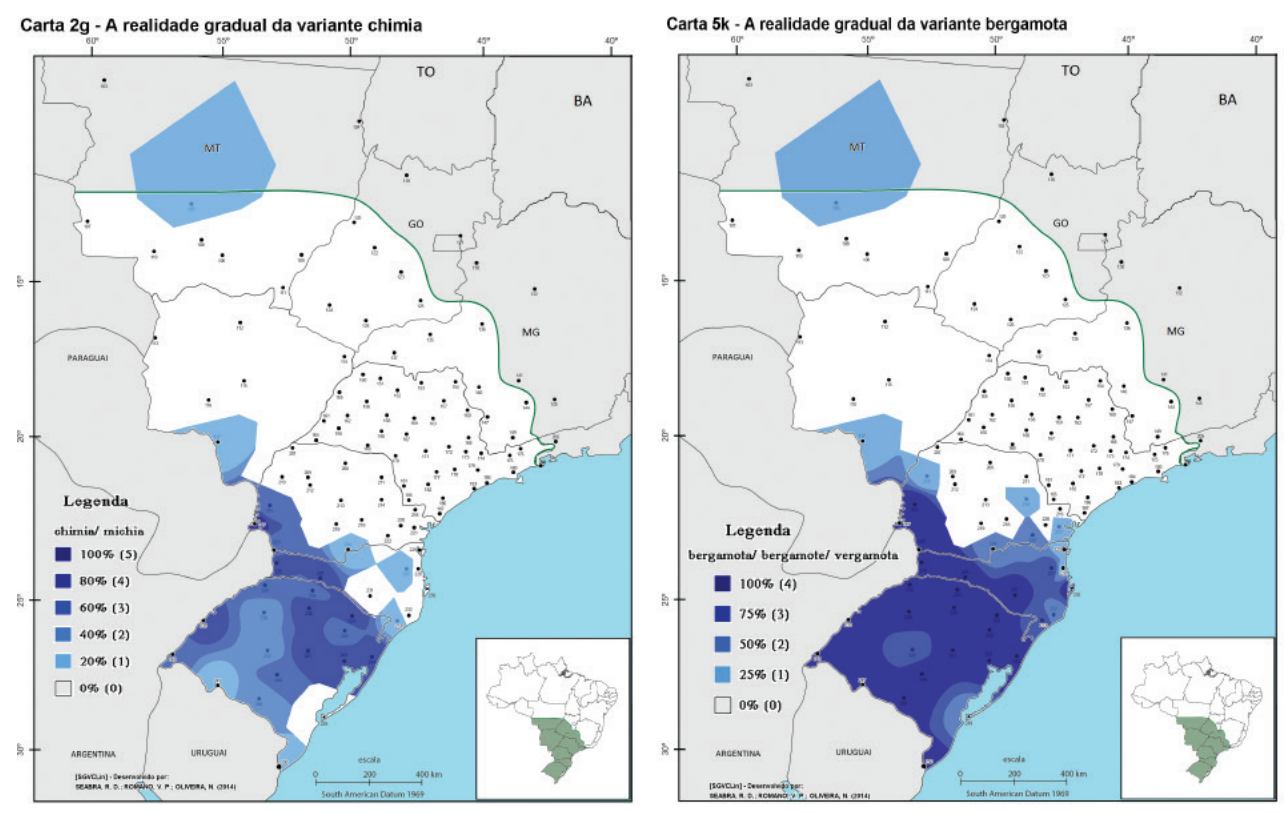

Fonte: Romano (2015).

Observa-se certa semelhança na distribuição espacial para os itens que correspondem parte do território do Rio Grande do Sul e por um corredor oeste de Santa Catarina, atinge o oeste paranaense e também se reflete no Mato Grosso do Sul. A incidência das variantes "chimia" 
e "bergamota" é mais intensa na parte meridional do território do subfalar sulista e, nas cartas selecionadas, evidenciam a presença de língua de imigração, como alemão, por exemplo, com ocorrência de "chimia", principalmente no nordeste e litoral norte do Rio Grande do Sul. "Bergamota" também traz fortemente a presença de língua de imigrantes, no caso, o italiano, principalmente no Rio Grande do Sul e oeste catarinense. A essa área lexical, cujos limites das linhas de isoléxicas são fluidos, Romano (2015) denomina como subfalar sulista de influência sul-rio-grandense, pois, à medida que adentra a parte setentrional do território, centro-norte do Paraná em direção ao território paulista, acaba perdendo força. Em contraponto à Figura 6, apresenta-se o contraste das formas "geleia" e "mexerica" na Figura 7.

FIGURA 7. Cartas linguísticas de "geleia" e "mexerica"
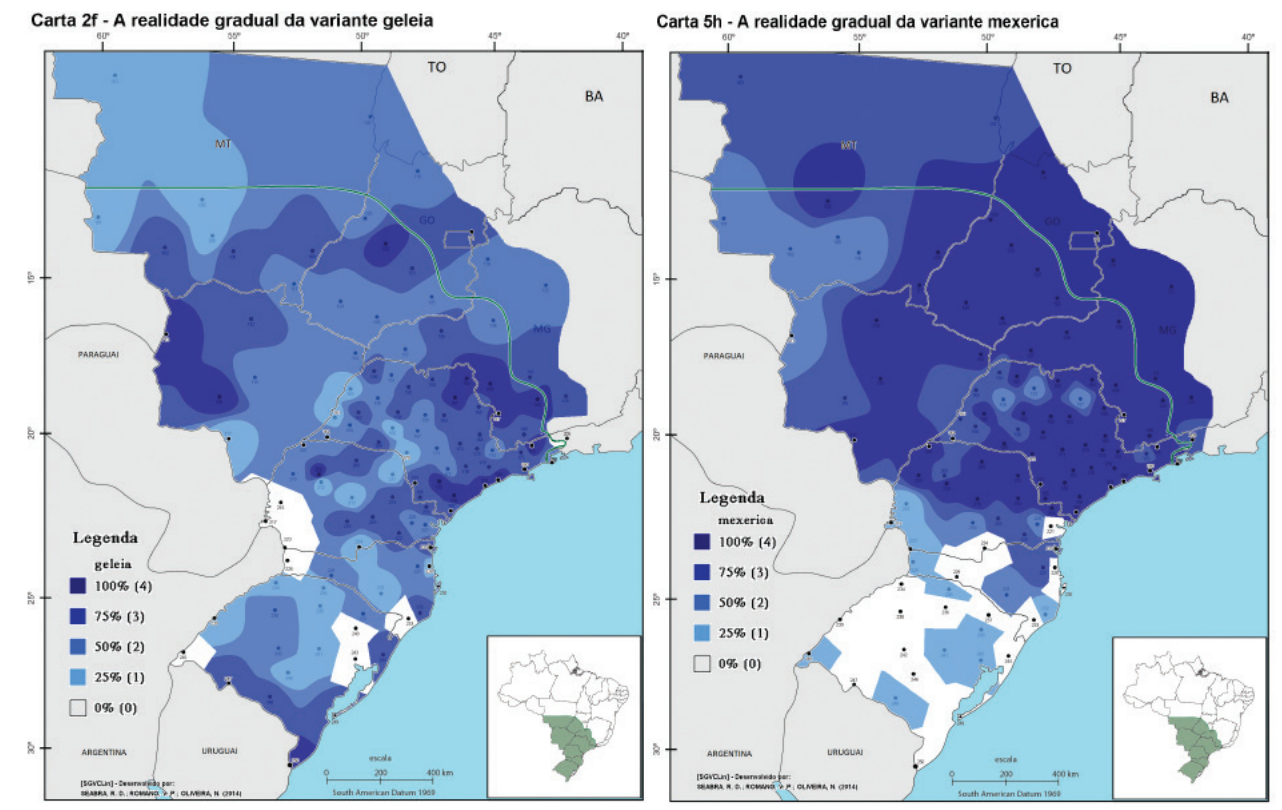

Fonte: Romano (2015).

Embora "geleia" seja o item amplamente difundido pelo território investigado, observa-se uma menor incidência em grande parte do território gaúcho e catarinense. A maior incidência de "geleia" se verifica principalmente no território paulista, que se expande para o Paraná Tradicional, a partir de um corredor do litoral paulista e também para ampla área do sul de Minas Gerais. "Mexerica”, por sua vez, está concentrada maciçamente no estado de São Paulo, expandindo-se no Norte do Paraná e pelos territórios mineiro, goiano e na região de fronteira com Mato Grosso e Mato Grosso do Sul.

Ressalte-se o quanto a variante "mexerica" não se apresenta em partes do território gaúcho ou em áreas com baixa incidência (uma ocorrência). De acordo com Romano (2015), tanto a variante "geleia" quanto a variante "mexerica" caracterizariam uma possível área do subfalar paulista em que há um menor número de variantes lexicais e predomínio de forma considerada padrão. Ou seja, uma área mais uniforme lexicalmente. Caracterizando esse possível subfalar paulista, a Figura 8 traz mais um exemplo com as variantes "córrego" e "bolinha de gude". 
FIGURA 8. Cartas linguísticas de "córrego" e "bolinha de gude"
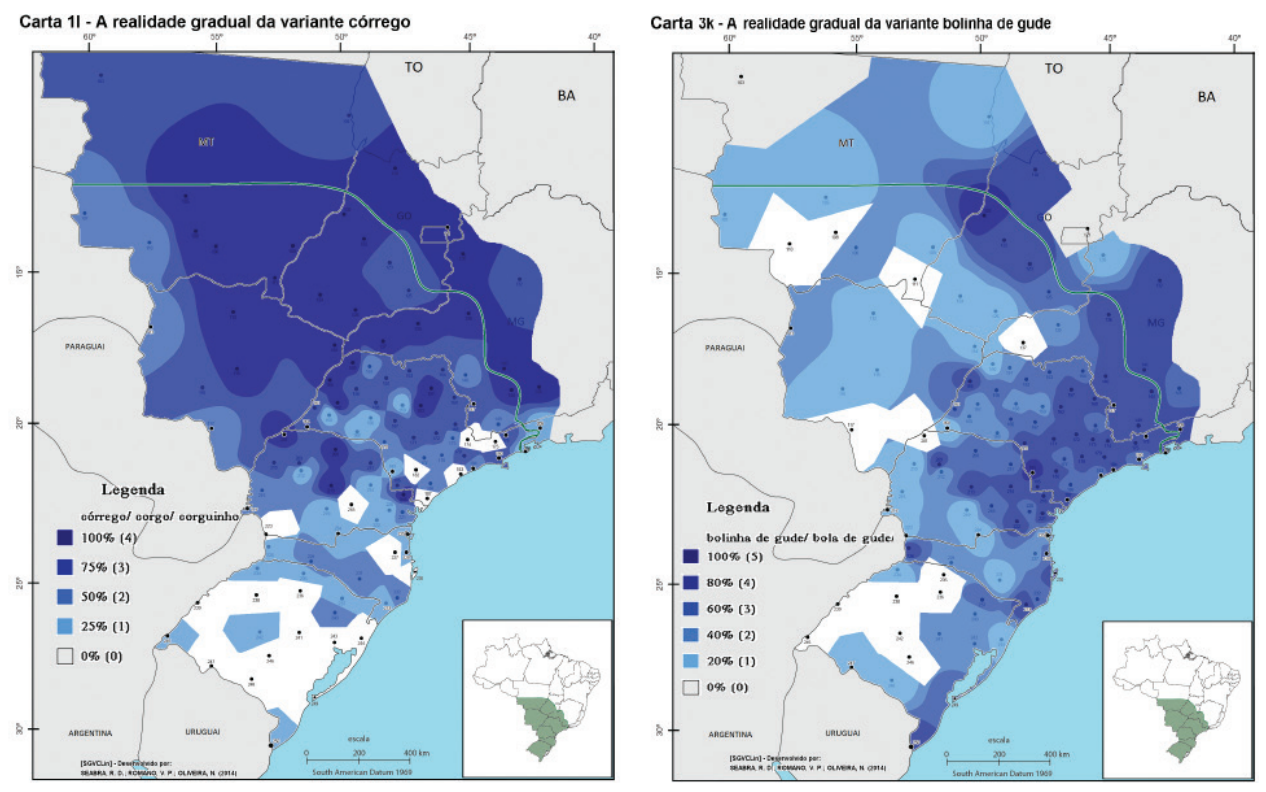

Fonte: Romano (2015).

Similarmente à Figura 7, a distribuição das duas formas consideradas padrão mais difundidas, segundo os lexicógrafos consultados por Romano (2015), localiza-se na parte setentrional do território do subfalar sulista, de Nascentes. "Córrego" encontra-se com maior incidência no estado de Goiás, parte do Mato Grosso, Mato Grosso do Sul, Triângulo Mineiro e Sul de Minas Gerais. Há ocorrência também em quase todo o estado de São Paulo, salvo alguns pontos, expandindo-se para o norte do Paraná e, à medida que adentra os estados da Região Sul, vai perdendo a produtividade. Há uma ampla área no Rio Grande do Sul que não ocorre "córrego" face à presença de outro item, "sanga" (Figura 9). A "bolinha de gude", por sua vez, apresenta-se predominantemente

FIGURA 9. Carta linguística das variantes "arroio" e "sanga"

\footnotetext{
Fonte: Romano (2015).
}

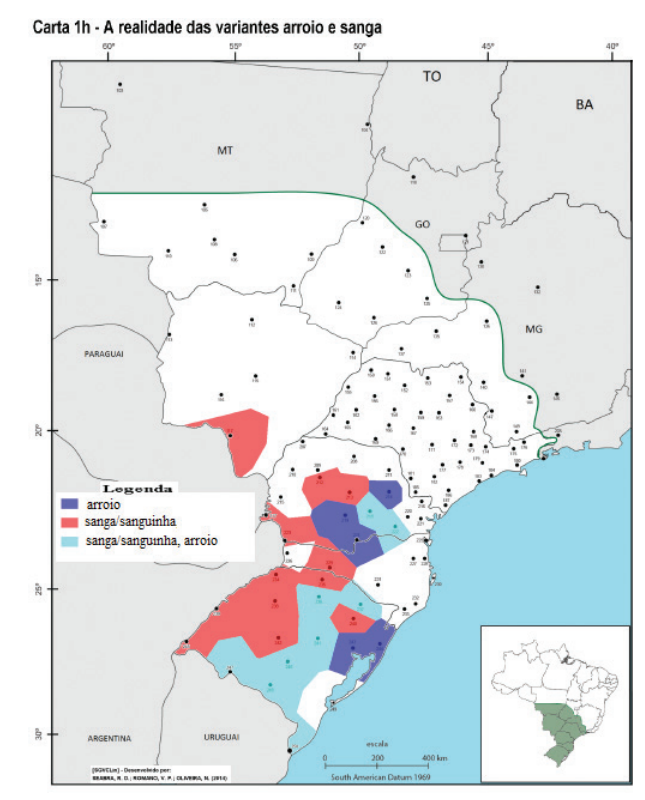


no estado de São Paulo, expandindo-se para Minas Gerais, refletindo-se também nos estados do Centro-Oeste, Paraná, Santa Catarina e Rio Grande do Sul com menor índice de ocorrência.

Uma ampla área, que corresponde quase todo o Rio Grande do Sul, oeste catarinense e centro-sul do Paraná, revela traços do português em contato com o espanhol com a presença de "sanga" (vermelho) delimitada pela linha de isoléxica para denominar o "córrego". Há uma área de central do Rio Grande do Sul, partindo do extremo Sul (Chuí) em que ocorrem tanto "sanga" quanto "arroio" (azul claro), e ainda uma área em que há ocorrência de "arroio" no litoral norte gaúcho e numa área do Paraná tradicional. Essa área em que ocorrem tanto a isoléxica quanto a heteroléxica de "arroio/sanga", segundo Romano (2015), pode ser identificada como área do subfalar sulista de influência sul-rio-grandense.

Na mesma linha, tem-se a Figura 10 que também traz a área do subfalar sulista de influência sul-rio-grandense, mas que não se limita aos estados da Região Sul, pois se propaga também para os estados de Mato Grosso do Sul com reflexos no Mato Grosso em decorrência de fluxos migratórios.

FIGURA 10. Cartas linguísticas das variantes "guri" e "bolita"
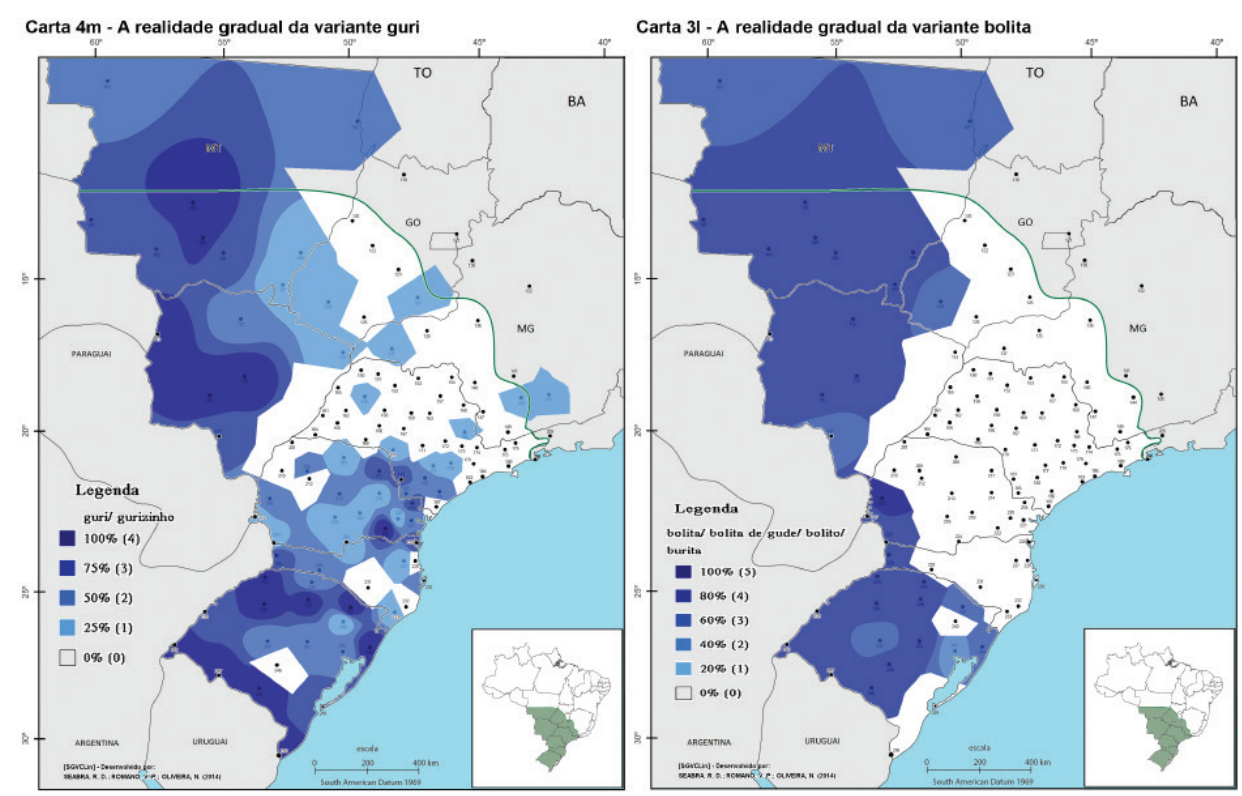

Fonte: Romano (2015).

A variante "guri", como designativo para a questão 132, está amplamente difundida nos estados da Região Sul, com diferentes índices de ocorrência, sendo mais produtiva, contudo, no Rio Grande do Sul, sobremaneira, no extremo sul (fronteira com Uruguai e em áreas do Mato Grosso do Sul e Mato Grosso). Em menor produtividade, expande-se para Santa Catarina, Paraná com reflexo no estado de São Paulo, seguindo caminho das antigas rotas dos tropeiros até Sorocaba (ROMANO, 2015). "Bolita”, como designativo para questão 156, por seu turno, revela traços do português em contato com o espanhol, mas não se reflete no estado de São Paulo e Paraná, com grande expansão para estados de Mato Grosso e Mato Grosso do Sul por um corredor do oeste catarinense e paranaense. Essa distribuição acompanha os movimentos de migração interno de gaúchos rumo aos estados do Centro-Oeste (ROMANO, 2015). 
Por última análise, mas que não encerra a discussão sobre uma possível bipartição do território do subfalar sulista de Nascentes (1953), na Figura 11, observam-se duas cartas linguísticas, uma com a distribuição areal de "guri" e "moleque" e outra de arealidade gradual apenas com a variante "moleque".

FIGURA 11. Cartas linguísticas das variantes gurie moleque

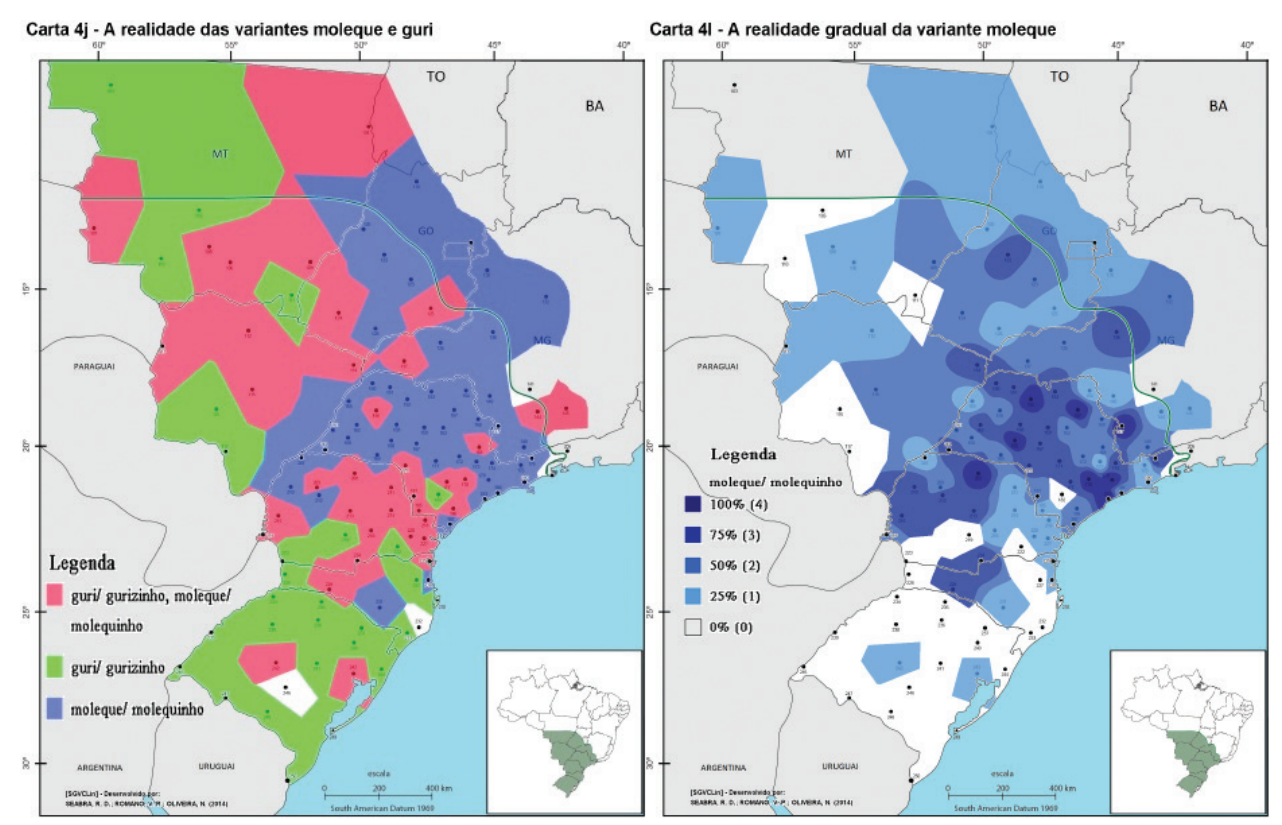

Fonte: Romano (2015).

Observa-se que a cor azul da imagem à esquerda revela a área de ocorrência do item "moleque" como denominativo para questão 132. Essa variante tem étimo africano (ROMANO, 2015), e concentra-se, principalmente, no estado paulista e se espalha em direção ao território mineiro, com reflexo também no norte do Paraná. Á área exclusiva de "guri" (cor verde), por sua vez, está principalmente no estado do Rio Grande do Sul e oeste catarinense. Há ocorrência de "guri" também no nordeste de Santa Catarina, além do Mato Grosso do Sul e Mato Grosso. As demais áreas, principalmente centro-sul do Paraná, apresentam a coocorrência de "guri" e "moleque" (cor vermelha). A carta de arealidade graudal de "moleque" (imagem à direita) revela maior concentração do item no território paulista e não ocorre no centro-oeste do Paraná, em grande parte do território catarinense e gaúcho. Ou seja, segundo Romano (2015), "guri" caracteriza um possível subfalar sulista de influência sul-rio-grandense que se expande para estados da Região Centro-Oeste e "moleque" caracteriza a possível área do subfalar paulista.

Em síntese, pelos exemplos aqui apresentados, observa-se que a área do território subfalar sulista de Antenor Nascentes (1953) pode ser dividida em dois possíveis subfalares, segundo as considerações e o estudo detalhado feito por Romano (2015). Em suas palavras:

O falar paulista difunde-se a partir do estado de SP, com influência na região norte do PR, oeste do MS, sudoeste e interior do Estado de GO, sul de MG e Triângulo mineiro [...] caracteriza-se por maior homogeneidade lexical na área geográfica, revelando um menor número de coocorrência de 
variantes lexicais [...] há o predomínio das formas mais produtivas que são consideradas padrão: córrego, geleia, bolinha de gude, menino, moleque, mexerica, poncã, que à medida que avançam para a porção sul do país apresentam uma diminuição no índice de ocorrência (ROMANO, 2015, p. 262).

Acerca da área do subfalar sulista, segundo Romano (2015, p. 263), localiza-se principalmente na parte meridional do Brasil, contemplando o estado do Rio Grande do Sul e, por um corredor do oeste catarinense e sudoeste paranaense, atinge o Estado do Mato Grosso do Sul.

Trata-se, portanto, de um falar de influência sul-rio-grandense que revela o contato do português com o espanhol em áreas de fronteira, e também de contato com língua de imigração como o alemão e o italiano, o que se evidencia por variantes presentes na norma lexical dos informantes, como sanga, arroio, chimia, bolita e bergamota (ROMANO, 2015, p. 263).

Ressalte-se que ambas as áreas têm seus limites fluidos e subáreas que ora se identificam com um ou com outro falar.

\section{0 subfalar fluminense}

Santos (2016) investigou a área denominada como subfalar fluminense, segundo proposição de Nascentes (1953). Na dissertação de mestrado, intitulada Brincando pelos caminhos do Falar Fluminense, defendida na Universidade Federal da Bahia, o referido autor ocupou-se em analisar os contornos dialetais da área escolhida e pontos de controle, que correspondem a cinco unidades federativas: Bahia, Minas Gerais, Espírito Santo, Rio de Janeiro e São Paulo. A pesquisa buscou verificar a variação lexical para 13 questões do Questionário Semântico-Lexical (QSL) (COMITE NACIONAL DO PROJETO ALiB, 2001), a saber:

- 155 - CAMBALHOTA: “... a brincadeira em que se gira o corpo sobre a cabeça e acaba sentado? (Mímica)";

- 156 - BOLINHA DE GUDE: “... as coisinhas redondas de vidro que os meninos gostam de brincar?";

- 157 - ESTILINGUE/SETRA/BODOQUE: “... o brinquedo feito de uma forquilha e duas tiras de borracha (mímica), que os meninos usam para matar passarinho?";

- 158 - PAPAGAIO DE PAPEL/PIPA: “... o brinquedo feito de varetas cobertas de papel que se empina no vento por meio de uma linha?";

- 159 - PIPA/ARRAIA: “... um brinquedo parecido com o (cf. item 158) também feito de papel, mas sem varetas, que se empina ao vento por meio de uma linha?";

- 160 - ESCONDE-ESCONDE: “... a brincadeira em que uma criança fecha os olhos, enquanto as outras correm para um lugar onde não são vistas e depois essa criança que fechou os olhos vai procurar as outras?";

- 161 - CABRA-CEGA: “... a brincadeira em que uma criança, com os olhos vendados, tenta pegar as outras?";

- 162 - PEGA-PEGA: “... uma brincadeira em que uma criança corre atrás das outras para tocar numa delas, antes que alcance um ponto combinado?"; 
- 163 - FERROLHO / SALVA / PICULA / PIQUE: “... esse ponto combinado?”;

- 164 - CHICOTE-QUEIMADO / LENÇO ATRÁS: “... uma brincadeira em que as crianças ficam em círculo, enquanto uma outra vai passando com uma pedrinha, uma varinha, um lenço que deixa cair atrás de uma delas e esta pega a pedrinha, a varinha, o lenço e sai correndo para alcançar aquela que deixou cair?";

- 165 - GANGORRA: “... uma tábua apoiada no meio, em cujas pontas sentam duas crianças e quando uma sobe, a outra desce?";

- 166 - BALANÇO: “... uma tábua, pendurada por meio de cordas, onde uma criança se senta e se move para frente e para trás?";

- 167 - AMARELINHA: “... a brincadeira em que as crianças riscam uma figura no chão, formada por quadrados numerados, jogam uma pedrinha (mímica) e vão pulando com uma perna só?"

A rede de pontos da pesquisa refere-se a 35 municípios, sendo em cada um deles entrevistados quatro informantes, nas localidades do interior, e oito informantes, nas capitais. Tais informantes estão estratificados em sexo (homem e mulher), faixa etária: Faixa I (18 a 30 anos) e Faixa II (50 a 65 anos) e escolaridade (fundamental e universitário - o último somente nas capitais), sumarizando a fala de 148 informantes. A análise dos dados ateve-se à dimensão diatópica, que foi prioritária, mas também os dados catalogados foram observados pela dimensão social.

Para este texto, foi feito um recorte para apresentar algumas considerações de cunho comparativo de formas registradas, adaptando-se as cartas linguísticas constantes do trabalho de Santos (2016). A Figura 12 apresenta a distribuição areal das formas "gangorra" (questão 165) e "balanço" (questão 166):

FIGURA 12. Cartas linguísticas das variantes "gangorra" e "balanço"
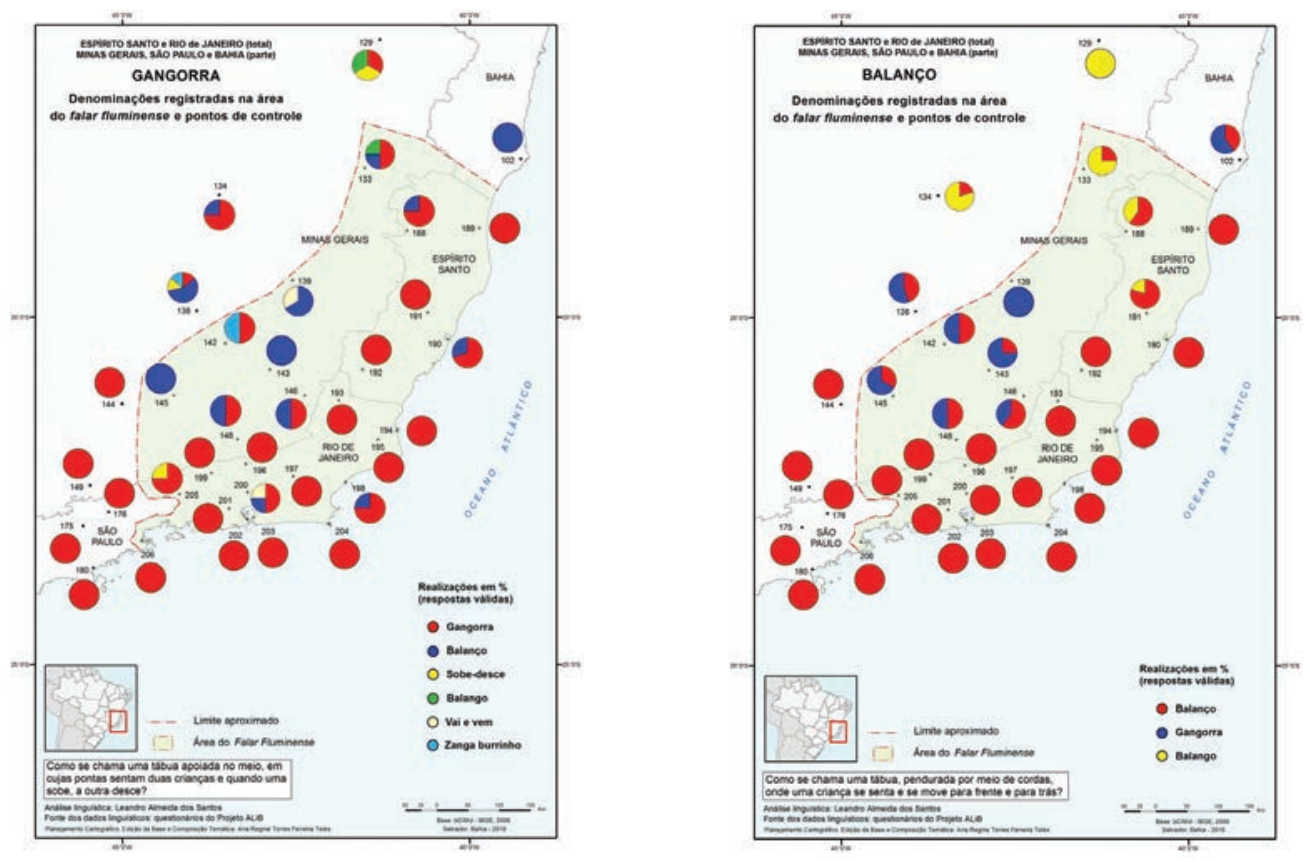

Fonte: Santos (2016). 
Ao observar a figura 12, nota-se uma similitude no que se refere à distribuição espacial para os itens lexicais cartografados, haja vista, em muitos pontos, a coocorrência de itens na parte norte dos estados do Espírito Santo e Minas Gerais, conforme assinalado por Santos (2016), com destaque para a parte central de Minais Gerais, tal área geográfica, de fato, apresenta, uma diversidade de itens lexicais, conforme se observa na figura 13.

FIGURA 13. Cartas linguísticas das variantes "pipa" e "amarelinha"
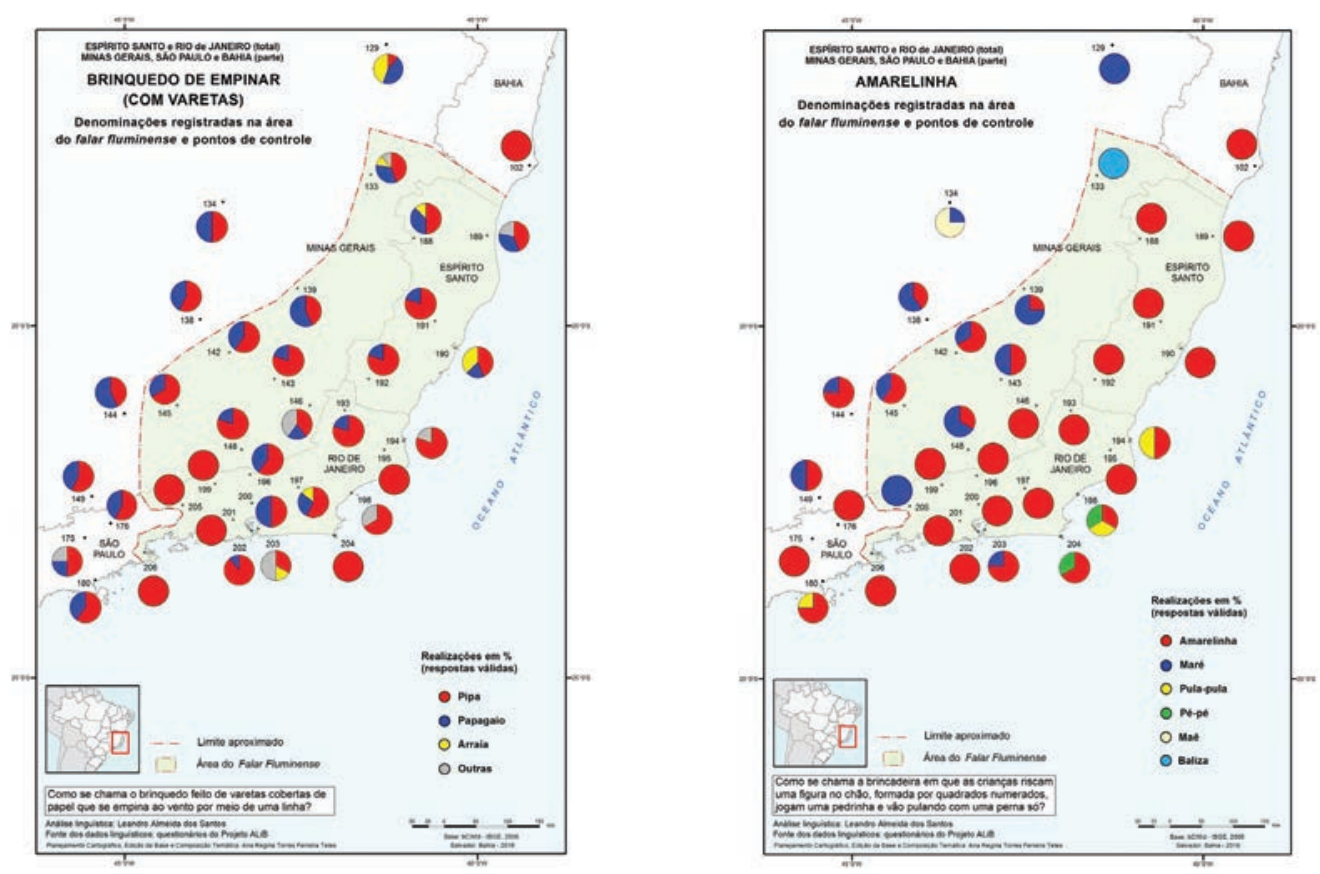

Fonte: Santos (2016).

A partir das análises apresentadas, sugere-se que pesquisas futuras se atentem para delimitação do subfalar mineiro, para trazer à tona, com mais precisão, os limites dialetais tanto deste subfalar quanto do subfalar fluminense, uma vez que este último não foi confirmado, conforme apontou Santos (2016):

Logo, a área do Falar Fluminense caracterizada por Nascentes, em 1953, com base em aspectos fonéticos e prosódicos, carece de novas pesquisas, uma vez que os itens apontam, por vezes, para o alargamento dessas linhas demarcatórias e, também, para o recuo delas, principalmente em direção às terras mineiras. Torna-se preponderante destacar, neste sentido, que estudos posteriores sobre o Falar Mineiro (NASCENTES, 1953) poderão fornecer dados elucidatórios, quando comparados com os dispostos nesta dissertação (SANTOS, 2016, p. 189).

Por última análise, no que tange aos limites do subfalar fluminense de Nascentes (1953), na Figura 14, observam-se duas cartas linguísticas, uma com a distribuição areal de "estilingue" e outra com a distribuição de "papagaio", dentro dos limites e nos pontos de controle, que apresentam uma diversidade de formas lexicais e um subfalar heterogêneo. 
FIGURA 14. Cartas linguísticas das variantes "estilingue" e "papagaio"
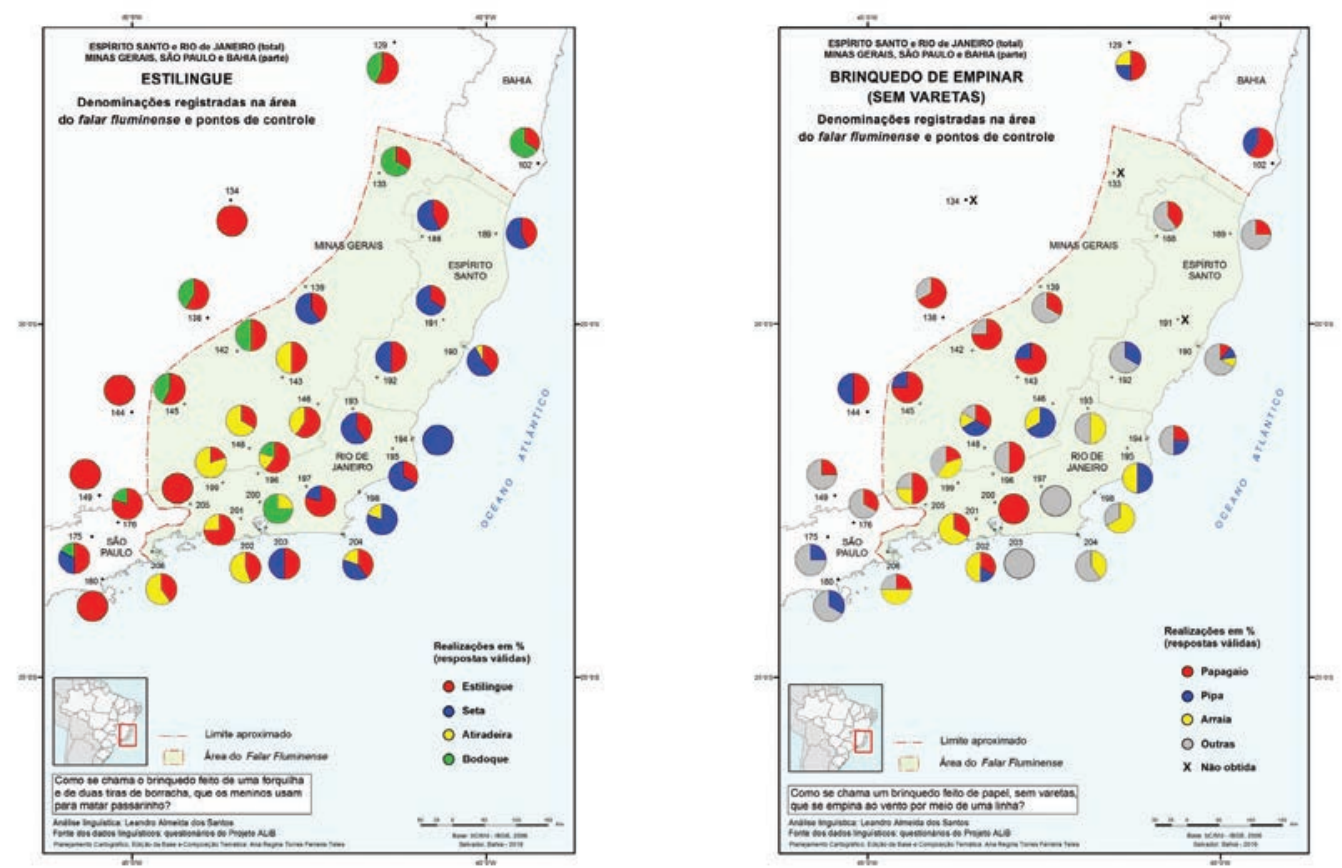

Fonte: Santos (2016).

Em resumo, nessa seção, pelos exemplos aqui expostos, observa-se que a área do subfalar fluminense de Antenor Nascentes (1953) necessita de mais pesquisas, haja vista que, por meio dos itens lexicais explorados no estudo feito por Santos (2016):

[...] no que tange às subdivisões dos falares do Sul, em especial à área do Falar Fluminense, tal proposição não pode ser considerada como válida, pois ora os dados evidenciam uma área linguística comum ora negam tal fato, não podendo, de fato, atestar uma unidade dialetal (SANTOS, 2016, p. 188).

Vale destacar a importância em explorar a socio-história das localidades, pois alguns fenômenos linguísticos sofrem influências externas, podendo encontrar possíveis explicações nos percursos feitos pelos homens, a partir dos diversos ciclos econômicos, por exemplo, no que concerne ao Brasil.

\section{Algumas considerações}

O tão almejado mapa dialetológico do Brasil, elaborado com base em dados empírico, por meio de uma recolha de dados uniforme e com metodologia única em todo o país, está em vias de ser construído. A equipe de pesquisadores do Projeto ALiB tem se dedicado nessa tarefa, inicialmente, sob a perspectiva lexical, mas que, pouco a pouco, adentra-se às descrições fonético-fonológicas e morfossintáticas que poderão evidenciar as áreas linguísticas refutando ou ratificando a proposta de Nascentes (1953).

Por ora, com base no que fora discutido aqui, pode-se afirmar que ao conjunto de falares do sul, há indícios de que, pelo menos, mais um subfalar poderia ser acrescentado, o subfalar 
paulista, uma vez que a grande área tão dialetologicamente distinta (Rio Grande do Sul e São Paulo) fora englobada pelo eminente filólogo e dialetólogo dentro de um mesmo território. $\mathrm{O}$ subfalar sulista estaria, portanto, localizado mais especificamente no território gaúcho, oeste catarinense e oeste do Paraná. Complementar a esse território, encontra-se o subfalar paulista ao norte, compreendendo São Paulo, norte do Paraná, com reflexos no Sul de Minas Gerais e estados limítrofes do Centro-Oeste brasileiro.

No que tange ao subfalar fluminense, em algumas cartas linguísticas, observou-se uma área bem heterogênea e que apresenta uma vasta diversidade de itens lexicais. Do ponto de vista lexical, a partir das análises empreendidas por Santos (2016), o subfalar fluminense não foi atestado, contrariando as proposições feitas, em 1953, por Antenor Nascentes. No entanto, destacam-se o norte do Espírito Santo, o norte e o centro de Minas Gerais, pois são áreas que revelaram coincidências. Em face disso, confirma-se a necessidade de pesquisas que explorem o subfalar mineiro in totum, uma vez que, conforme a proposição de Zágari (2005), há somente três falares mineiros, a saber: baiano, mineiro e paulista.

Seguindo as recomendações de Nascentes (1955), em prol de uma delimitação mais precisa, com base em dados empíricos, a equipe de pesquisadores do Projeto ALiB segue perseguindo o tão almejado marco dialetológico. Portanto, destaca-se a relevância dos volumes já publicados do Atlas Linguístico do Brasil (CARDOSO et al., 2014), volumes 1 e 2, para o entendimento das diversas faces dialetais brasileiras, a partir dos dados das capitais. No entanto, os volumes que estão por vir, sobretudo, os volumes 6 e 7, com dados das cidades interioranas, somados aos dados das capitais, permitirão uma melhor visualização da atual situação dialetal do Brasil, podendo confirmar ou refutar as delimitações nascentistas.

\section{REFERÊNCIAS}

AGUILERA, Vanderci de Andrade. Léxico e áreas dialetais: o que podem demonstrar os dados do ALIB. ANAIS - VI Congresso Internacional da Abralin / Dermeval da Hora (org.). - João Pessoa: Ideia, 2009. v. 2, p. 4219-4233.

AMARAL, Amadeu. O dialeto capira: gramática, vocabulário. 4. Ed. São Paulo: HUCITEC; Brasília: INL, 1981 [1920].

CARDOSO, Suzana Alice Marcelino. Tinha Nascentes razão? Considerações sobre a divisão dialetal do Brasil. Estudos Linguísticos e Literários. Salvador: UFBA, n. 5, 1986, p. 47-59.

CARDOSO, Suzana Alice Marcelino. Vogais médias pretônicas no Brasil: uma visão diatópica. In.: AGUILERA, Vanderci de Andrade. (org.). Português no Brasil: estudos fonéticos e fonológicos. Londrina: EDUEL, 1999, p. 95-108.

CARDOSO, Suzana Alice Marcelino. et al. Atlas linguístico do Brasil, v. 1 (Introdução). Londrina: EDUEL, 2014a.

CARDOSO, Suzana Alice Marcelino. et al. Atlas linguístico do Brasil, v. 2 (Cartas linguísticas). Londrina: EDUEL, 2014b. 
CINTRA, Luís Filipe Lindley. Estudos de Dialectologia Portuguesa. 2. ed. Lisboa: Sá da Costa, 1995.

COMITÊ NACIONAL DO PROJETO ALiB: Atlas Lingüístico do Brasil: Questionários. Londrina: UEL, 2001.

COSERIU, Eugenio. O homem e sua linguagem. Trad. Carlos A. da Fonseca; Mário Ferreira. Rio de Janeiro: Presença, 1987.

D’ANUNCIAÇÃO, Eliana Souza. Registrando o léxico dos brinquedos e brincadeiras infantis em Minas Gerais. 2016. 86f. Monografia (Graduação em Letras) - Universidade Federal da Bahia, Salvador, 2016.

KOCH, Walter; ALTENHOFEN, Cléo Vilson; KLASSMANN, Mário Silfredo. (orgs.). Atlas Linguístico-Etnográfico da Região Sul do Brasil - ALERS: cartas fonéticas e morfossintáticas. Porto Alegre: Editora da UFRGS; Florianópolis: Ed. UFSC, 2002.

MOTA, Jacyra Andrade. Áreas dialetais brasileiras. In: CARDOSO, Suzana Alice Marcelino; MOTA, Jacyra Andrade; MATTOS e SILVA, Rosa Virginia. (orgs.) Quinhentos anos de história Linguística do Brasil. Salvador: Secretaria de Cultura e Turismo do Estado da Bahia, 2006. p. 319-357.

NASCENTES, Antenor. Études dialectologiques du Brésil. ORBIS - Bulletin International de Documentat ion Linguistique, Louvain , t. 2, n. 2, p. 438-444, 1953.

NASCENTES, Antenor. O linguajar carioca. 2.ed. Completamente refundida. Rio de Janeiro. Organização Simões, 1953.

NASCENTES, Antenor. O linguajar carioca em 1922. Rio de Janeiro: Süssekind de Mendonça, 1922.

NASCENTES, Antenor. Bases para elaboração do Atlas Linguístico do Brasil. Rio de Janeiro: Ministério da Educação e Cultura, Casa Rui Barbosa, 1958.

NASCENTES, Antenor. Divisão dialectológica do território brasileiro. Revista Brasileira de Geografia, Rio de Janeiro, v. 17, n. 2, abr./jun, p. 213-219, 1955.

PORTILHO, Danyelle Almeida Saraiva. O falar amazônico: uma análise da proposta de Nascentes (1953) a partir de dados do Projeto ALiB. 2013. 155p. Dissertação (Mestrado em Estudos de Linguagens) - Universidade Federal do Mato Grosso do Sul, Campo Grande, 2013.

RIBEIRO, Silvana Soares Costa. Brinquedos e brincadeiras infantis na área do "Falar Baiano". 2012. 752f. Tese (Doutorado em Letras). Universidade Federal da Bahia, Salvador. 2012.

ROMANO, Valter Pereira. Em busca de falares a partir de áreas lexicais no centro-sul do Brasil. 2015, 402f. Tese (Doutorado em Estudos da Linguagem) - Universidade Estadual de Londrina, Londrina, 2015.

ROMANO, Valter Pereira. Áreas lexicais brasileiras: um novo olhar sobre a proposta de Antenor Nascentes nos dados do Projeto Atlas Linguístico do Brasil. Linguística. vol. 34, número 1, p. 117-145, Montevideo, jun. 2018.

ROSSI, Nelson. Atlas Prévio dos Falares Baianos. Rio de Janeiro: Ministério de Educação e Cultura; Instituto Nacional do Livro, 1963.

SANTOS, Leandro Almeida dos. Brincando pelos caminhos do Falar Fluminense. 2016. 197f. Dissertação (Mestrado em Língua e Cultura) Universidade Federal da Bahia, Salvador. 2016. 
SANTOS, Graziele Ferreira da Silva. O léxico dos jogos e diversões infantis no corpus do Projeto ALiB: visitando o Falar Nordestino. 207f. Dissertação (Mestrado em Língua e Cultura) Universidade Federal da Bahia, Salvador, 2018.

TELES, Ana Regina Torres Ferreira. Cartografia e Georreferenciamento na Geolinguística: revisão e atualização das regiões dialetais e da rede de pontos para a elaboração do Atlas Linguístico do Brasil formuladas por Antenor Nascentes. 2018. 483f. Tese (Doutorado em Língua e Cultura). Universidade Federal da Bahia, Salvador, 2018.

ZÁGARI, Mário Roberto Lobo. Os Falares Mineiros: Esboço de um Atlas Lingüístico de Minas Gerais. In: Vanderci de Andrade Aguilera. (org.). A Geolingüística no Brasil - trilhas seguidas, caminhos a percorrer. 1ed. Londrina: Editora da Universidade Estadual de Londrina, 2005, v. 1, p. 45-72. 